dr inz. Zygmunt Marciniak

dr inz. Ireneusz Pielecha

Instytut Pojazdów Szynowych ,Tabor”

\title{
Badania silników lokomotyw spalinowych w świetle dopuszczeń do eksploatacji na torach polskich linii kolejowych
}

\begin{abstract}
Artykut poświęcony jest zagadnieniom badania silników spalinowych pojazdów trakcyjnych, zwlaszcza lokomotyw, sprowadzanych do kraju z zagranicy. Przedstawiono dopuszczalne limity zawartości składników toksycznych $w$ spalinach emitowanych do atmosfery przez silniki stosowane $w$ spalinowych pojazdach trakcyjnych wedlug różnych przepisów $i$ dyrektyw. Ponadto zaprezentowano aparature wraz z metodyka badań i zasadami określania poziomów emisji najważniejszych składników toksycznych oraz przedstawiono wyniki badań prowadzonych na lokomotywach (sprowadzanych zazwyczaj z zagranicy), zarówno z silnikami remontowanymi jak $i$ z nowymi silnikami wymienianymi w ramach napraw i modernizacji.

W zakończeniu przedstawiono wskazówki dla spetnienia przez silniki spalinowe określonych wymagań w zakresie emisji sktadników toksycznych.
\end{abstract}

\section{Wstęp}

$\mathrm{Na}$ przestrzeni ostatnich kilku lat zostaje sprowadzanych do kraju coraz większa liczba spalinowych pojazdów trakcyjnych (zwłaszcza lokomotyw), których silniki spalinowe nie spełniają wymagań w zakresie emisji do atmosfery składników toksycznych występujących w spalinach. Spowodowane jest to przede wszystkim liberalizacją przewozów kolejowych w kraju i pojawieniem się ponad trzydziestu przewoźników (tzw. operatorów prywatnych), nie skupionych w byłych i obecnych strukturach Polskich Kolei Państwowych S.A.

Operatorzy ci, do których należą między innymi Chem Trans Logistic (CTL) S.A., PCC Rail Szczakowa S.A., PTK i GK Sp. z o.o. w Zabrzu, PTK i GK S.A. w Rybniku, Lotos Kolej Sp. z o.o. z Gdańska, Pol-Miedź-Trans Sp. z o.o. z Lubina, przewożą obecnie około $10 \%$ wszystkich towarów w transporcie kolejowym, a ich udziały w rynku od 2002 roku rosną przeciętnie o $60 \div 100 \%$ rocznie.

Przewoźnicy prywatni w 2005 roku rozpoczęli również ekspansję $\mathrm{w}$ zakresie przewozów pasażerskich, uruchamiając ruch regionalny $\mathrm{z}$ wykorzystaniem autobusów szynowych produkcji krajowej. Wzrost przewozów towarowych realizowanych przez operatorów prywatnych odbywa się oczywiście kosztem największego przewoźnika towarów masowych, tj. PKP Cargo S.A.

Szybki rozwój przewozów to również duże inwestycje w zakresie sprawnej obsługi m.in. dla kontrolowania kosztów i informacji o przewozach a więc: czasach załadunku, formowania składów pociagów, uruchamiania i podczepiania lokomotyw, miejsca przebywania pociagu w danym czasie, oraz inwestycje w zakresie pozyskiwania taboru, zwłaszcza wagonów towarowych i lokomotyw.
Wyrosła konkurencja dla PKP Cargo S.A., które wysłużony tabor wagonowy i lokomotywowy przeznacza je na złom a brak krajowej produkcji taniego, trwałego i niezawodnego taboru zmusza prywatnych operatorów do jego poszukiwań i zakupów za granicami naszego kraju. Zaczęto więc sprowadzać do Polski zużyty już tabor trakcyjny, a w tym lokomotywy spalinowe, z wielu krajów europejskich - najwcześniej z Niemiec, Czech, Słowacji, Rumunii oraz krajów nadbałtyckich, a ostatnio czyni się starania o ich pozyskanie również z Rosji i Ukrainy dla obsługi linii szerokotorowych.

Sprowadzane lokomotywy spalinowe (na tych pojazdach trakcyjnych skupiono się $\mathrm{w}$ artykule przede wszystkim) są w różnym stanie technicznym, nie są zarówno młode wiekiem jak i mają przestarzałe rozwiązania układów elektrycznych i mechanicznych (lata 60-te i 70-te XX w.) oraz wymagaja napraw, modernizacji oraz tzw. „polonizacji” tj. zabiegów umożliwiających ich bezpieczną eksploatację na torach Polskich Linii Kolejowych S.A. Zakupowane lokomotywy spalinowe mają w większości przestarzałe silniki spalinowe (najczęściej dwusuwowe).

Chociaż ze względu na niższe koszty duża ilość lokomotyw jest naprawiana i modernizowana w krajach sąsiedzkich, to w kraju lokomotywy poddawane są:

- naprawom głównym silników spalinowych wraz ze szczegółowymi regulacjami i wymianami zużytych elementów, aparatów i urządzeń związanych z silnikami

- wymianom (tzw. remotoryzacjom) silników spalinowych na nowsze i nowocześniejsze, spełniające określone wymagania $\mathrm{w}$ zakresie 
trwałości, niezawodności, zużycia paliwa i oleju smarnego, a przede wszystkim oddziaływania na środowisko naturalne człowieka.

Każda $\mathrm{z}$ takich naprawianych lub remotoryzowanych lokomotyw, jeżeli nie posiada udokumentowanych wyników prób i badań silników, zostaje poddawana badaniom m.in. związanym $\mathrm{z}$ określeniem zawartości głównych składników toksycznych w emitowanych na zewnatrz spalinach.

Wynika to z zakresu badań, koniecznych do uzyskania świadectwa dopuszczenia do eksploatacji typu pojazdów kolejowych, opublikowanego w Rozporządzeniu Ministra Infrastruktury z dnia 12.10.2005 r, (Dz.U. Nr 212 poz. 1772).

Ponadto przewiduje się, że każda remontowana lokomotywa spalinowa (dotyczy to również innych spalinowych pojazdów trakcyjnych) podczas naprawy rewizyjnej, a zwłaszcza głównej, będzie poddawana specjalistycznym badaniom silnika spalinowego na okoliczność składników toksycznych w emitowanych spalinach. Z tego względu w IPS „Tabor” Poznań w ostatnich latach i obecnie przygotowano szczegółowe warunki techniczne dla lokomotyw spalinowych sprowadzanych z zagranicy i doposażanych w urządzenia i układy gwarantujące bezpieczeństwo ruchu na krajowej sieci kolejowej.

\section{Przepisy i normy regulujące ocenę silników spalinowych pojazdów szynowych}

$\mathrm{W}$ ostatnich latach $\mathrm{w}$ Europie, $\mathrm{w}$ tym również $\mathrm{w}$ kraju, zwraca się coraz baczniejszą uwagę na ochronę środowiska naturalnego człowieka. Dotyczy to nie tylko emisji substancji szkodliwych przez przemysł, w tym huty, elektrownie, zakłady ciepłownicze, ale również emisji składników toksycznych do atmosfery przez środki transportu, w tym transportu szynowego.

Generalnie w Europie obowiązują dwa główne przepisy, regulujące wymagania dla silników spalinowych pojazdów trakcyjnych $\mathrm{w}$ zakresie dopuszczalnych składników toksycznych zawartych w spalinach emitowanych do atmosfery. Sa to wymagania ujęte $\mathrm{w}$ raporcie ERRI (dawniej ORE) [15] oraz w kartach UIC $[12,18]$, nie mających jednak umocowania prawnego $\mathrm{w}$ świetle prawa międzynarodowego, a są tylko zobowiązaniami wszystkich kolei skupionych w UIC (Międzynarodowym Związku Kolejowym) [11].

Z przepisów tych korzysta się jednak nadal dla oceny zastosowanych silników w spalinowych pojazdach trakcyjnych. Obecnie, w związku z pojawieniem się na rynku europejskim (unijnym) wielu prywatnych operatorów realizujących przewozy zwłaszcza towarów, zostały wydane Dyrektywy mające moc prawa unijnego, w których określono szczegółowo wymagania $\mathrm{w}$ zakresie dopuszczalnych emisji składników toksycznych spalin. Wymagania te dotyczą zarówno pojazdów drogowych jak i szynowych z różnymi rodzajami silników spalinowych i są bardzo ważne również w przypadku zastosowania silników samochodowych do spalinowych pojazdów trakcyjnych (np. w lekkich pojazdach, autobusach szynowych, pojazdach pomocniczych).

Badania silników spalinowych pojazdów trakcyjnych prowadzone są według różnorodnych testów określonych zarówno w przepisach i normach kolejowych jak i dyrektywach Parlamentu Europejskiego.

Poniżej przedstawiono skrótowe informacje o poszczególnych testach oraz dopuszczalne limity składników toksycznych ujętych w poszczególnych przepisach i normach:

- test badawczy dwudziestodziewięciofazowy wg Raportu ORE B13 Rp22 [15], przy czym do analiz obliczeniowych z 29 punktów pomiarowych (zależnie od prędkości obrotowej minimalnej, przez prędkości pośrednie do maksymalnych oraz od mocy minimalnej do maksymalnej) przyjmuje się tylko cztery, dobrane równomiernie dla badanego silnika spalinowego (obowiązuje dla silników produkowanych w tym okresie).

Dopuszczalne limity składników toksycznych w spalinach przedstawiono w tabeli 1 .

Limity emisji spalin wg ORE B13 Rp22

Tabela 1

\begin{tabular}{|c|c|c|c|c|}
\hline Data $\begin{array}{l}\text { Eprowadzenia } \\
\text { (obowiązywania) }\end{array}$ & $\begin{array}{c}\text { CO } \\
\text { (tlenek } \\
\text { węgla) }\end{array}$ & $\begin{array}{l}\mathrm{NO}_{\mathrm{x}} \\
\text { (tlenki } \\
\text { azotu) }\end{array}$ & $\begin{array}{c}\text { HC } \\
\text { (wegglo- } \\
\text { wodory) }\end{array}$ & $\begin{array}{c}\text { Zaczer- } \\
\text { nienie } \\
\mathbf{k}\left[\mathbf{m}^{-1}\right]\end{array}$ \\
\hline Do 31.12.1981 & 12 & 24 & 4 & $1,6 \div 2,5$ \\
\hline Od 01.01.1982 & 8 & 20 & 2,4 & $1,6 \div 2,5$ \\
\hline Od 01.02.1991 & 4 & 16 & 1,6 & $1,6 \div 2,5$ \\
\hline Od 01.02.1997 & 3 & 12 & 0,8 & $1,6 \div 2,5$ \\
\hline
\end{tabular}

- test badawczy według PN-EN ISO 8178-4 cykl F [17] uwzględniający trzy punkty pomiarowe obciążenia silnika spalinowego: na biegu jałowym (60\% dla obrotów biegu jałowego, bez obciążenia), biegu pośrednim (15\% dla obrotów pośrednich i około $50 \%$ obciążenia) oraz na biegu maksymalnym $(25 \%$ dla obrotów max i 100\% obciążenia).

Dopuszczalne limity emisji według obowiązujących jeszcze kart UIC $[12,18]$ przedstawiono w tabeli 2.

- test badawczy według PN-EN ISO 8178-4 cykl C1 [17] dla silników zabudowywanych przede wszystkim w lekkich pojazdach szynowych np. autobusach szynowych. Cykl C1 uwzględnia ocenę dla ośmiu punktów pomiarowych, zależnych od obciążenia i tzw. współczynników ważonych. 


\begin{tabular}{|c|c|c|c|c|c|}
\hline \multicolumn{2}{|c|}{ 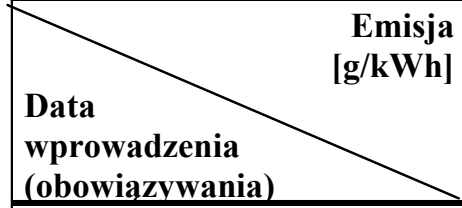 } & $\begin{array}{c}\text { CO } \\
\text { (tlenek } \\
\text { węgla) }\end{array}$ & $\begin{array}{c}\mathrm{NO}_{\mathrm{x}} \\
\text { (tlenki azotu) }\end{array}$ & $\begin{array}{c}\text { HC } \\
\text { (węglo- } \\
\text { wodory) }\end{array}$ & $\begin{array}{c}\text { PM } \\
\text { cząstki } \\
\text { stałe }\end{array}$ \\
\hline \multicolumn{2}{|c|}{ Do 31.12.2002 UIC I } & 3 & 12 & 0,8 & $1,6(2,5)^{*}$ \\
\hline \multirow{2}{*}{$\begin{array}{l}\text { Od } \\
01.01 .2003 \\
\text { UIC II }\end{array}$} & $\begin{array}{l}\text { Dla } \\
\mathrm{P} \leq 560 \mathrm{~kW}\end{array}$ & 2,5 & 6 & 0,6 & 0,25 \\
\hline & $\begin{array}{l}\text { Dla } \\
\mathrm{P}>560 \mathrm{~kW}\end{array}$ & 3 & $\begin{array}{r}\text { dla } \mathrm{n}>1000 \mathrm{obr} / \min 9,5 \\
\mathrm{n} \leq 1000 \mathrm{obr} / \mathrm{min} 9,9\end{array}$ & 0,8 & 0,25 \\
\hline \multirow[t]{2}{*}{$\begin{array}{l}\text { Od } \\
01.01 .2008\end{array}$} & $\begin{array}{l}\text { Dla } \\
\mathrm{P} \leq 560 \mathrm{~kW}\end{array}$ & 2 & 4,6 & 0,5 & 0,15 \\
\hline & $\begin{array}{l}\text { Dla } \\
\mathrm{P}>560 \mathrm{~kW}\end{array}$ & 2 & 6 & 0,5 & 0,2 \\
\hline
\end{tabular}

- Dopuszczalne limity emisji dla poszczególnych etapów wprowadzania według Dyrektywy Komisji Europejskiej przedstawiono w tabeli $3[13,14]$.

Limity emisji spalin wg Dyrektywy 2004/26 (nowelizacja dyrektywy 97/68) Komisji Europejskiej

Tabela 3

\begin{tabular}{|c|c|c|c|c|c|c|c|c|}
\hline \multicolumn{2}{|c|}{$\begin{array}{l}\text { Data } \\
\text { wprowadzenia } \\
\text { (obowiazywania) }\end{array}$} & $\begin{array}{c}\text { Typ (rodzaj) } \\
\text { pojazdu trakcyj- } \\
\text { nego } \\
\text { i jego moc } \\
\text { w kW } \\
\end{array}$ & $\mathrm{CO}$ & $\mathrm{HC}$ & HC+NOx & NOx & PM & $\begin{array}{c}\text { Rodzaj cyklu } \\
\text { badawczego wg } \\
\text { PN-EN ISO } \\
8178-4\end{array}$ \\
\hline \multirow{4}{*}{ IIIA } & $\begin{array}{c}\text { RCA } \\
\left.01.07 .05 / 01.01 .06^{*}\right)\end{array}$ & $\begin{array}{l}\text { Wagon motorowy } \\
\mathrm{P}>130\end{array}$ & 3,5 & - & 4 & - & 0,2 & $\mathrm{C} 1$ \\
\hline & $\begin{array}{c}\text { RLA } \\
\left.01.01 .06 / 01.01 .06^{*}\right)\end{array}$ & $\begin{array}{c}\text { Lokomotywa } \\
130<\mathrm{P}<560\end{array}$ & 3,5 & - & 4 & - & 0,2 & $\mathrm{~F}$ \\
\hline & $\begin{array}{c}\text { RHA } \\
\left.01.01 .08 / 01.01 .09^{*}\right)\end{array}$ & $\begin{array}{l}\text { Lokomotywa } \\
\mathrm{P}>560\end{array}$ & 3,5 & 0,5 & - & 6 & 0,2 & $\mathrm{~F}$ \\
\hline & $\begin{array}{c}\text { RHA } \\
\left.01.01 .08 / 01.01 .09^{*}\right)\end{array}$ & $\begin{array}{c}\text { Lokomotywa } \\
\mathrm{P}>2000 \\
\text { i pojemność cylin- } \\
\mathrm{dra}>5 \mathrm{dm}^{3}\end{array}$ & 3,5 & 0,4 & - & 7,4 & 0,2 & $\mathrm{~F}$ \\
\hline \multirow{2}{*}{ IIIB } & $\begin{array}{c}\text { RCB } \\
\left.01.01 .11 / 01.01 .12^{*}\right) \\
\end{array}$ & $\begin{array}{l}\text { Wagon motorowy } \\
\mathrm{P}>130\end{array}$ & 3,5 & 0,19 & - & 2 & 0,025 & $\mathrm{C} 1$ \\
\hline & $\begin{array}{c}\mathrm{RB} \\
\left.01.01 .11 / 01.01 .12^{*}\right)\end{array}$ & $\begin{array}{c}\text { Lokomotywa } \\
\mathrm{P}>130\end{array}$ & 3,5 & - & 4 & - & 0,025 & $\mathrm{C} 1$ \\
\hline
\end{tabular}

Ponadto dla pojazdów szynowych, w których zostaną zastosowane silniki samochodowe z zapłonem samoczynnym, zarówno na olej napędowy jak i paliwa gazowe, zalecane były i będą badania według następujących testów $[13,14]$ :

- ECE R49 - test europejskiej komisji gospodarczej (agenda ONZ)

- ESC - stacjonarny test europejski
- ELR - obciążeniowy test europejski

- ETC - europejski test niestacjonarny.

Dopuszczalne limity emisji składników toksycznych spalin emitowanych do atmosfery przez badane $\mathrm{i}$ oceniane silniki według wyszczególnionych testów ujętych w poszczególnych Dyrektywach Parlamentu Europejskiego (Komisji Europejskiej) przedstawiono w tabelach 4, 5 i $6\lceil 13,14\rceil$. 
Limity emisji spalin wg Dyrektyw 1999/96/EC i 2001/27/EC Parlamentu Europejskiego dla spalinowych silników samochodowych z zapłonem samoczynnym o mocach powyżej $85 \mathrm{~kW}$

Tabela 4

\begin{tabular}{|c|c|c|c|c|c|c|c|}
\hline \multicolumn{2}{|c|}{$\begin{array}{l}\text { Data } \\
\text { wprowadzenia } \\
\text { (obowiazywania) }\end{array}$} & \multirow{2}{*}{$\begin{array}{c}\begin{array}{c}\text { Rodzaj } \\
\text { testu }\end{array} \\
\text { ECE R49 } \\
\end{array}$} & \multirow{2}{*}{$\begin{array}{r}\text { CO } \\
4,5 \\
\end{array}$} & \multirow{2}{*}{$\begin{array}{c}\text { HC } \\
1,1 \\
\end{array}$} & \multirow{2}{*}{$\begin{array}{c}\text { NO }_{\mathbf{x}} \\
8 \\
\end{array}$} & \multirow{2}{*}{$\begin{array}{c}\begin{array}{c}\text { PM } \\
\text { (cząstki } \\
\text { stałe) }\end{array} \\
0,612 \\
\end{array}$} & \multirow[t]{2}{*}{$\begin{array}{c}\begin{array}{c}\text { Zaczernie- } \\
\text { nie } \\
{\left[\mathbf{k}^{-1}\right]}\end{array} \\
- \\
\end{array}$} \\
\hline Euro I & 01.01 .1992 & & & & & & \\
\hline \multirow{2}{*}{ Euro II } & 01.10 .1996 & \multirow{2}{*}{ ECE R49 } & 4 & 1,1 & 7 & 0,25 & - \\
\hline & 01.10 .1998 & & 4 & 1,1 & 7 & 0,15 & - \\
\hline \multirow{2}{*}{ Euro III } & 01.01 .1999 & \multirow{4}{*}{ ESC i ELR } & 1,5 & 0,25 & 2 & 0,02 & 0,15 \\
\hline & 01.10 .2000 & & 2,1 & 0,66 & 5 & 0,10 & 0,8 \\
\hline Euro IV & 01.10 .2005 & & 1,5 & 0,46 & 3,5 & 0,02 & 0,5 \\
\hline Euro V & 01.10 .2008 & & 1,5 & 0,46 & 2 & 0,02 & 0,5 \\
\hline
\end{tabular}

Limity emisji spalin wg Dyrektyw 2004/26/EC i 2005/13/EC Parlamentu Europejskiego dla silników o mocach $130 \mathrm{~kW} \geq P \leq 560 \mathrm{~kW}$

Tabela 5

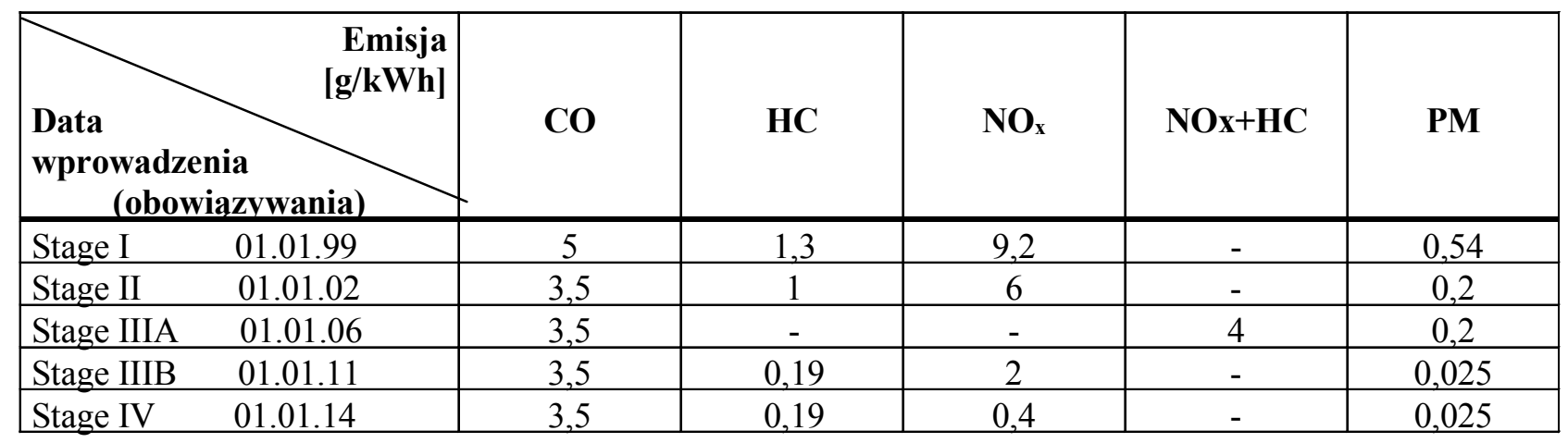

Limity emisji spalin wg Dyrektyw 1995/96/EC i 2001/27/EC Parlamentu Europejskiego dla silników wysokoprężnych zasilanych olejem napędowym i gazem wg testu ETC (europejski test niestacjonarny)

Tabela 6

\begin{tabular}{|c|c|c|c|c|c|c|}
\hline \multicolumn{2}{|c|}{ Data } & $\begin{array}{c}\text { CO } \\
\text { (tlenek } \\
\text { węgla) }\end{array}$ & $\begin{array}{c}\text { NMHC } \\
\text { (węglowo- } \\
\text { dory } \\
\text { bez udziału } \\
\text { metanu) } \\
\end{array}$ & $\begin{array}{c}\mathrm{CH}_{4} \\
\text { (metan- } \\
\text { silniki na } \\
\text { gaz ziemny) }\end{array}$ & $\begin{array}{c}\text { NO }_{x} \\
\text { (tlenki azo- } \\
\text { tu) }\end{array}$ & $\begin{array}{c}\text { PM } \\
\text { (cząstki } \\
\text { stałe) }\end{array}$ \\
\hline \multirow{2}{*}{ Euro III } & 01.10 .1999 & 3 & 0,4 & 0,65 & 2 & 0,02 \\
\hline & 01.10 .2000 & 5,45 & 0,78 & 1,6 & 5 & 0,16 \\
\hline Euro IV & 01.10 .2005 & 4 & 0,55 & 1,1 & 3,5 & 0,03 \\
\hline Euro V & 01.10 .2008 & 4 & 0,55 & 1,1 & 2 & 0,03 \\
\hline
\end{tabular}

Oczywistym jest, że dla nowoprojektowanych pojazdów szynowych o zakresie badania silników spalinowych i zakresie spełnienia określonych wymagań zadecyduje przede wszystkim użytkownik lub zamawiający, przedstawiając szczegółowe wytyczne techniczno-eksploatacyine. 
3. Aparatura badawcza, metodyka pomiarów i zasady określania emisji składników toksycznych

\subsection{Aparatura badawcza}

Do wyznaczania emisji, a w zasadzie stężeń poszczególnych składników toksycznych spalin emitowanych przez silniki spalinowe, Instytut Pojazdów Szynowych „Tabor” i Instytut Silników Spalinowych i Transportu Wydziału Maszyn Roboczych i Transportu Politechniki Poznańskiej dysponuje dwoma układami (systemami) pomiarowymi:

- Mexa 7100D japońskiej firmy Horiba

- Testo 360 niemieckiej firmy Testo Osteuropa $\mathrm{GmbH}$.

Pierwszy z nich (rys. 1, ze schematem połączeń jego modułów przedstawionym na rys. 2) służy do pomiarów składników toksycznych spalin metodami homologacyjnymi, których zakresy dobierane są odpowiednio do przewidywanych stężeń związków toksycznych zawartych w spalinach silnika.
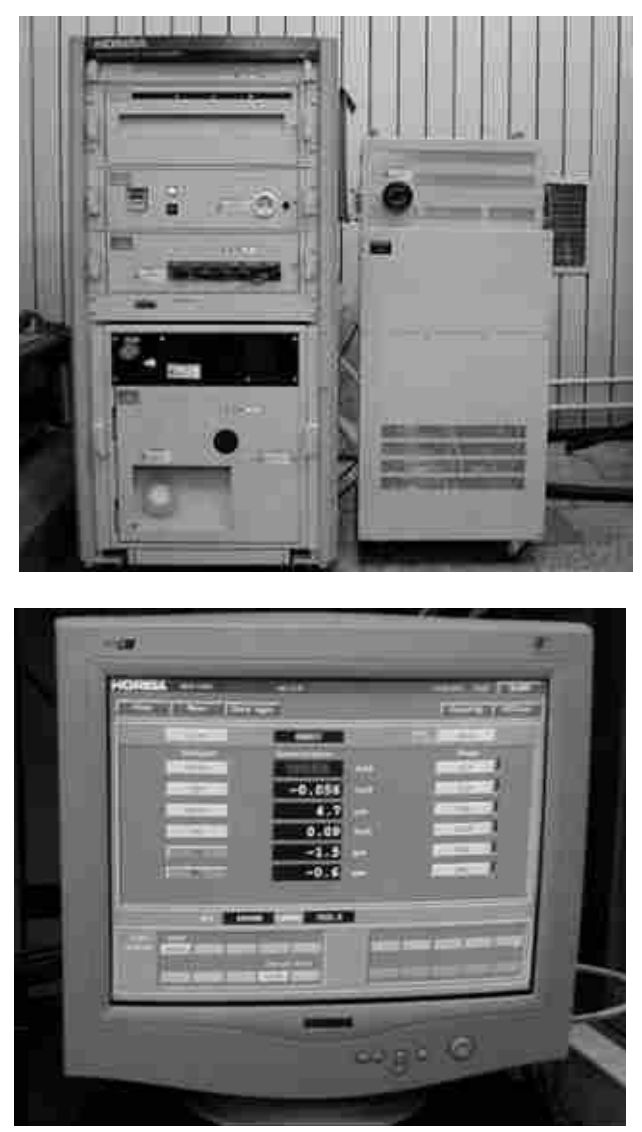

Rys. 1. Aparatura badawcza systemu Mexa 7100D firmy Horiba
Ze względu na długotrwały okres przygotowania aparatury, w tym kalibracja - dobór stężeń gazów kalibracyjnych do mierzonych składników spalin i ich zakresów, zalecane jest stosowanie aparatury pomiarowej dla przeprowadzenia badań, w których zależy nam na wysokiej dokładności, a więc w zasadzie do pomiarów doświadczalnych i homologacyjnych [1].

Drugi z układów - analizator Testo 360 ze zintegrowanym komputerem przenośnym PC (notebook) może być wykorzystywany do pomiarów i analizy składników toksycznych spalin silników po naprawach rewizyjnych i głównych.

Analizator Testo 360 zawiera detektor gazu i detektor do pomiaru ciśnienia (do wyznaczania prędkości przepływu), procesor gazu z chłodnica, system przepompowania gazu oraz zawory rewersyjne do automatycznej kalibracji przy pomocy gazu wzorcowego i automatycznego przedmuchu $\mathrm{z}$ sondą wielofunkcyjną.

$\mathrm{Na}$ analizatorze znajdują się złącza do podłączenia wszelkich sond, detektorów oraz przyłącza gazowe $[5,6]$.

Ogólny widok analizatora przedstawiono na rys. 3 , a osprzęt do opracowania wyników na rys. 4 .

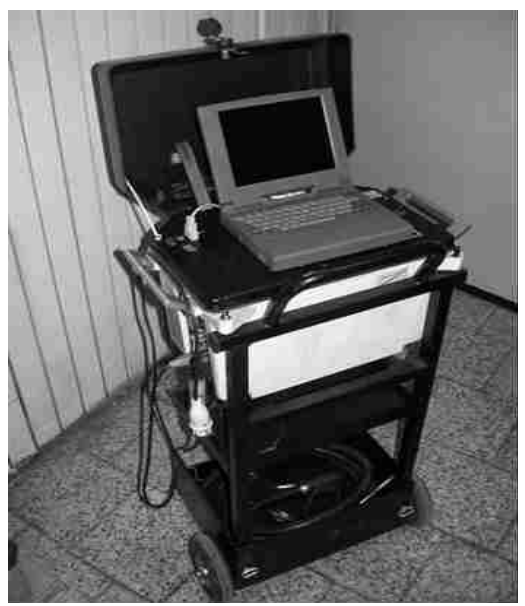

Rys. 3. Analizator spalin Testo 360 ogólny widok 


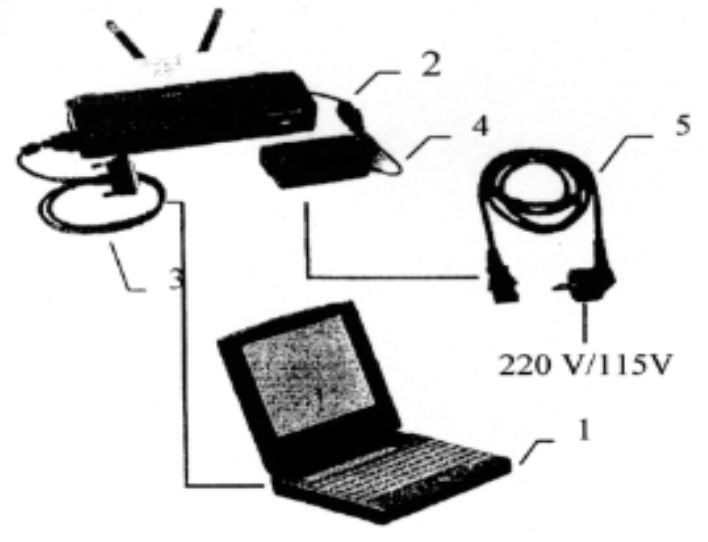

Rys.4. Osprzęt do opracowania wyników: 1 - komputer przenośny (notebook); 2 - minidrukarka, 3 - kabel łączący drukarki, 4 - zasilacz drukarki, 5 - kabel zasilacza drukarki
W skład analizatora, którego schematyczną budowę przedstawiono na rys. 5, wchodzą następujące zespoły i urządzenia:

- analizator $\mathrm{z}$ modułami pomiarowymi $\mathrm{CO}$, $\mathrm{CO}_{2}, \mathrm{NO}, \mathrm{NO}_{2}, \mathrm{HC}, \mathrm{O}_{2}$

- przenośny komputer PC

- złącze

- złącze szeregowe

- zasilacz przenośny PC

- kabel zasilający analizator

- wąż gazu ogrzanego

- $\quad$ kabel zasilania sondy wielofunkcyjnej

- sonda spalin

- filtr świeżego powietrza (oczyszczacz CO).

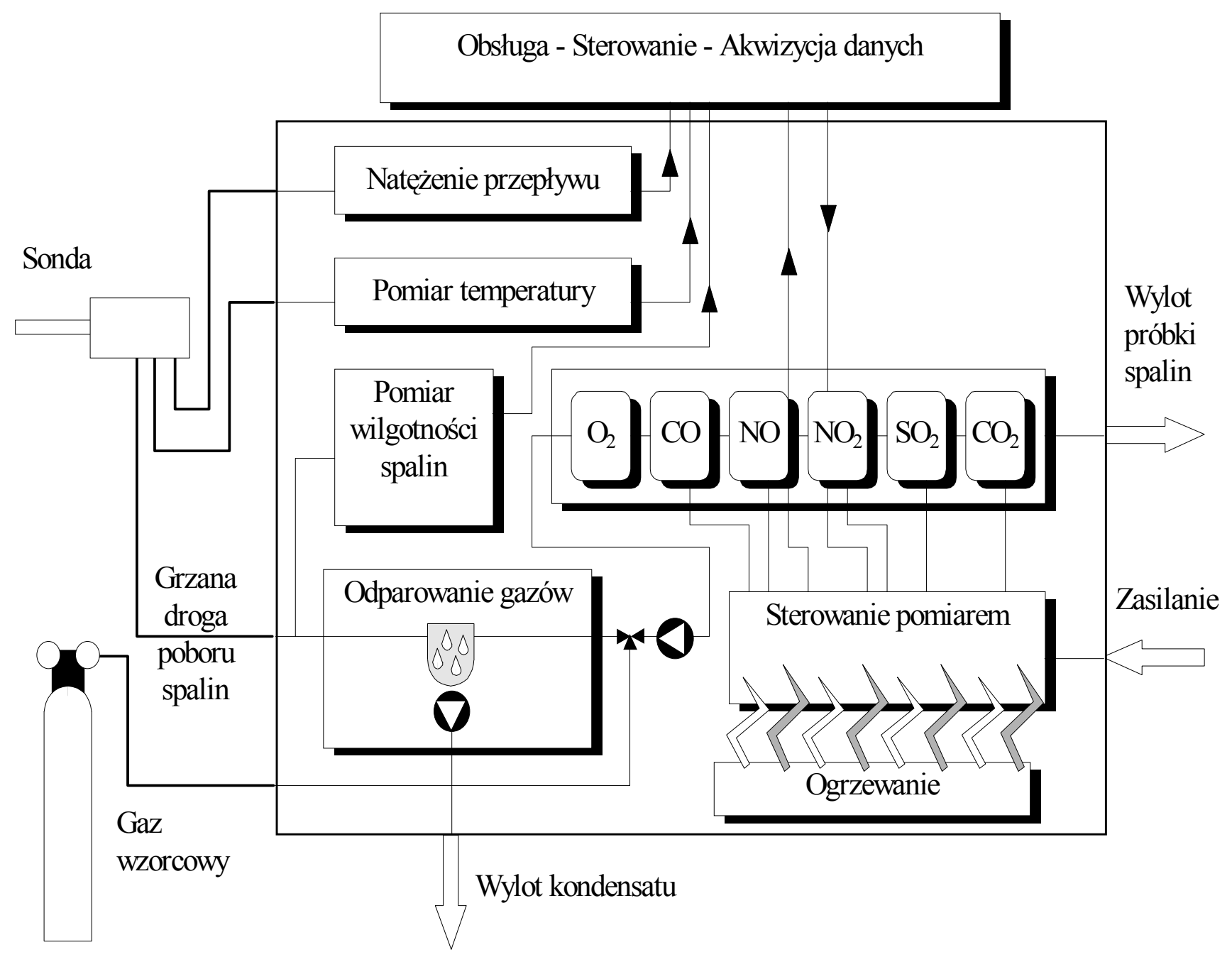

Rys. 5. Schemat budowy analizatora składników toksycznych spalin 


\subsection{Metodyka pomiarów}

Badania emisji składników toksycznych silników spalinowych po naprawie i niezbędnych regulacjach prowadzone są dla określenia następujących składników:

- tlenku węgla CO [ppm]

- węglowodorów HC [ppm]

- tlenków azotu $\mathrm{NO}_{x}[\mathrm{ppm}]$

- dwutlenku węgla $\mathrm{CO}_{2}[\%]$

gdzie: ppm - milionowa część jedności (parts per million) z uwzględnieniem tła pomiarowego.

Badania przeprowadza się najczęściej na oporniku służącym zazwyczaj do określania charakterystyki zespołu prądotwórczego według procedury obejmującej [2]:

- przygotowanie silnika spalinowego do pomiarów w zakresie:

- stabilizacji stanu cieplnego oleju silnikowego

- stabilizacji stanu cieplnego cieczy chłodzącej

- ustalenia minimalnej prędkości obrotowej silnika, odpowiadającej początkowej pozycji nastawnika jazdy (dla obrotów biegu jałowego)

- przygotowanie aparatury pomiarowej do badań w zakresie:

- stabilizacji temperaturowej urządzenia

- zerowania

- zamontowania sondy pomiarowej do poboru próbki spalin

- pomiar poszczególnych składników toksycznych spalin dla przyjętego testu, a w zasadzie faz testu dla przyjętych mocy i prędkości obrotowych wału korbowego silnika.

\subsection{Zasady wyznaczania emisji składników tok- sycznych spalin}

Wyznaczanie emisji składników toksycznych spalin (na podstawie pomierzonych wartości $\mathrm{CO}, \mathrm{HC}$, $\mathrm{NO}_{\mathrm{x}}$ i $\mathrm{CO}_{2}$ dla poszczególnych pozycji nastawnika jazdy) najczęściej odbywa się za pomocą:

- wyznaczania (obliczania) metodą homologacyjną

- wyznaczania z wykorzystaniem danych technicznych producenta danego silnika

- wyznaczania na podstawie szacowania wielkości niezbędnych do obliczeń.

W metodzie - algorytmie pierwszym przy znanych udziałach w paliwie węgla, wodoru i siarki wyznaczanie emisji w $\mathrm{g} / \mathrm{kWh}$ odbywa się w następującej kolejności:

- oblicza się zapotrzebowanie powietrza do spalania stechiometrycznego
- oblicza się współczynnik nadmiaru powietrza przy całkowitym spalaniu i koncentracji dwutlenku węgla

- oblicza się stosunek wodoru do węgla

- wyznacza się masowe natężenie przepływu powietrza suchego

- określa się współczynnik charakteryzujący paliwo jako stosunek koncentracji mokrej spalin do koncentracji suchej

- wyznacza się zawartość węglowodorów w suchych spalinach

- oblicza się masę spalin

- oblicza się masę powietrza mokrego

- wyznacza się masowe natężenie emisji (dla spalin mokrych) poszczególnych składników spalin (tj. CO, HC, NOx) dla każdej fazy cyklu

- oblicza się faktyczne (średnie) wartości poszczególnych składników tj. $\mathrm{CO}, \mathrm{HC}$ i $\mathrm{NO}_{\mathrm{x}}$ $\mathrm{w}$ g/kWh wg normy PN-EN ISO 8178-1 [16] i według PN-EN ISO 8178-4 [17] dla określonego cyklu (najczęściej typu F).

Dokładne i szczegółowe zasady wyznaczania emisji poszczególnych składników toksycznych wraz ze wzorami i zależnościami przedstawione są $\mathrm{w}$ cytowanych normach.

W metodzie drugiej - algorytm wyznaczania emisji składników toksycznych spalin sprowadza się do następujących obliczeń i określeń:

- dokonuje się pomiarów rzeczywistych $\mathrm{CO}$, $\mathrm{HC}, \mathrm{NO}_{\mathrm{x}}$ i $\mathrm{CO}_{2}$ w spalinach dla poszczególnych pozycji nastawnika jazdy (prędkości obrotowych i mocy cząstkowych)

- wykorzystując dane producenta silnika na podstawie prędkości obrotowej określa się natężenie przepływu powietrza (Gpow)

- wykorzystując pomierzone stężenie dwutlenku węgla określa się współczynnik nadmiaru powietrza $(\lambda)$

- dysponując wartościami Gpow i $\lambda$ określa się wydatek paliwa $(\mathrm{Ge})$

- oblicza się wydatek spalin (Gsp) jako sumę wydatku powietrza Gpow i paliwa Ge

- wyznacza się godzinową emisję poszczególnych składników toksycznych $\mathrm{w}$ g/h jako iloczyn wydatku spalin, stężeń (skorygowanych) składników toksycznych i współczynników dla danego składnika

- uwzględniając pomiarowe moce dla poszczególnych pozycji nastawnika (poszczególnych faz badawczych) i współczynników udziału faz wyznacza się końcowe wartości emisji poszczególnych składników toksycznych spalin w $\mathrm{g} / \mathrm{kWh}$. 
Metodę trzecią stosuje się w przypadku braku możliwości przeprowadzenia pomiarów zużycia paliwa i powietrza. Polega ona na określeniu rzeczywistej emisji składników toksycznych spalin na następującej podstawie:

- dokonuje się pomiarów rzeczywistych $\mathrm{CO}$, $\mathrm{HC}, \mathrm{NO}_{\mathrm{x}}$ i $\mathrm{CO}_{2}$ w spalinach dla poszczególnych prędkości obrotowych i mocy cząstkowych

- określa się teoretyczne natężenie przepływu powietrza (Gt) na podstawie cząstkowych prędkości obrotowych silnika

- określa się współczynnik napełnienia $\left(\eta_{V}\right)$

- na podstawie natężenia przepływu powietrza, współczynnika napełnienia i ciśnienia doładowania, wyznacza się rzeczywisty wydatek powietrza (Gpow)

- określa się współczynnik nadmiaru powietrza $(\lambda)$ na podstawie wyznaczonego rzeczywistego stężenia dwutlenku węgla $w$ spalinach

- określa się rzeczywisty wydatek paliwa (Ge) wykorzystując wyznaczony wcześniej rzeczywisty wydatek powietrza (Gpow) i współczynnik nadmiaru powietrza $(\lambda)$

- oblicza się wydatek spalin (Gsp) jako sumę wydatku paliwa $(\mathrm{Ge})$ i powietrza (Gpow)

- oblicza się godzinowa emisje składników szkodliwych jako iloczyn wydatku spalin, skorygowanych stężeń składników toksycznych oraz współczynników dla danego składnika

- wyznacza się ostateczną wielkość poszczególnych składników toksycznych spalin (w $\mathrm{g} / \mathrm{kWh}$ ) uwzględniając pomierzone moce dla poszczególnych faz badawczych (pozycji nastawnika) i współczynników udziału faz.

$\mathrm{Na}$ zakończenie dla każdej z metod dokonuje się porównania otrzymanych wyników $\mathrm{z}$ wartościami dopuszczalnymi ujętymi w normach, kartach UIC, czy też Dyrektywach Parlamentu Europejskiego. Podobnie postępuje się również w przypadku wykorzystania innych cykli badawczych np. C1.

Należy również zaznaczyć, że pierwsza z metod (najdokładniejsza) wykorzystywana jest przy wyznaczaniu emisji spalin podczas badań silnika na stanowisku badawczym.

W normalnej eksploatacji po przeprowadzonych naprawach i regulacjach silników spalinowych pojazdów trakcyjnych, najlepsze będzie stosowanie metody drugiej, a w wyjątkowych przypadkach z braku danych metody trzeciej.

Otrzymane wyniki obliczeń uzyskiwanych w metodzie drugiej i trzeciej będa jednak obarczone błędem nie przekraczającym $\pm 5 \%$, co przy tego rodzaju badaniach (dla dopuszczenia pojazdów do ruchu) jest dopuszczalne i nie będzie budzić zastrzeżeń.

\section{Badania i wyniki pomiarów emisji składników toksycznych spalin przez silniki lokomotyw spalinowych}

\subsection{Obiekty badań}

Badania przeprowadzono $\mathrm{w}$ większości na lokomotywach sprowadzonych z zagranicy (Niemcy, Słowacja, Estonia, Bułgaria) i poddanych w krajowych i zagranicznych zakładach naprawczych taboru kolejowego naprawom głównym lub remotoryzacjom.

W jednym przypadku pomiarów składników toksycznych dokonano na polskiej lokomotywie manewrowej, która została doposażona w urządzenia bezpieczeństwa ruchu dla spełnienia wymagań dopuszczenia do ruchu po torach Polskich Linii Kolejowych S.A.

Pomiary składników toksycznych realizowano równolegle ze sprawdzeniem charakterystyki zespołu prądotwórczego na opornikach wodnych w Pesa Bydgoszcz, Zakładzie Taboru Poznań, Bumarze-Fablok Chrzanów, Zakładach Naprawczych Taboru Kolejowego Poznań [3, 4, 5, 6, 7, 8, 9].

Parametry badanych silników spalinowych niezbędne do oceny emisji składników toksycznych spalin wraz z przyporządkowaniem do lokomotyw, na których zostały silniki zabudowane, przedstawiono $\mathrm{w}$ tabeli 7.

\subsection{Wyniki pomiarów emisji składników toksycz- nych z silników lokomotyw spalinowych}

Pomiary emisji składników toksycznych spalin prowadzono na przestrzeni $2004 \div 2006$ roku, przede wszystkim na lokomotywach remontowanych (naprawianych). W przypadkach uzyskiwania wyników odbiegających wyraźnie od limitów (wartości dopuszczalnych) pomiary, po wprowadzeniu wymian zużytych elementów (np. wtryskiwaczy) oraz przeprowadzeniu dodatkowych regulacji w układzie paliwowym, były powtarzane.

Poniżej podano wyniki badań silników poszczególnych lokomotyw według PN-EN ISO 8178-1 dla cyklu $\mathrm{F}$ wraz $\mathrm{z}$ odniesieniami do obowiązujących przepisów i norm $[10,12,15 \div 18]$ :

1. Lokomotywa V200 (ST44) - badana w 2004 r. na oporniku wodnym w ZNTK Poznań - rys. 6 [3].

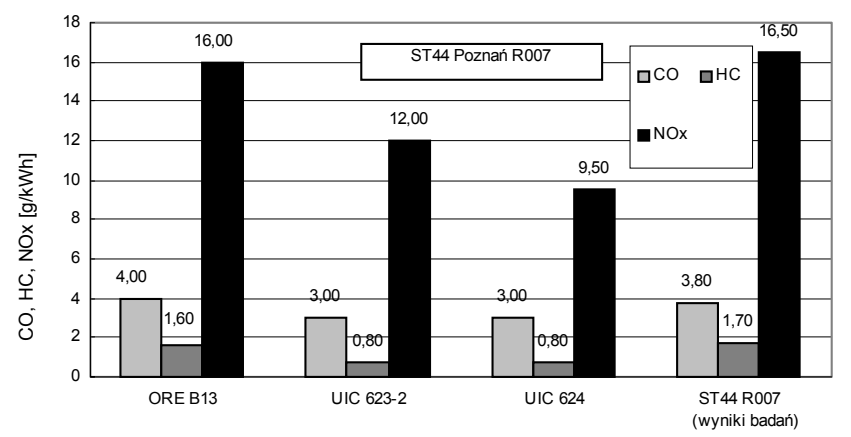

Rys. 6. Wyniki badań emisji spalin dla silnika 14D40 lokomotywy V200 (ST44) po przeprowadzonych regulacjach i wymianie zużytych elementów 
Tabela 7

\begin{tabular}{|c|c|c|c|c|c|c|c|c|c|c|}
\hline \multirow[b]{2}{*}{ Lp. } & \multirow{2}{*}{$\begin{array}{c}\text { Typ/seria } \\
\text { badanej } \\
\text { lokomo- } \\
\text { tywy } \\
\text { spalino- } \\
\text { wej }\end{array}$} & \multirow{2}{*}{$\begin{array}{l}\text { Typ bada- } \\
\text { nego silnika } \\
\text { spalinowego }\end{array}$} & \multirow{2}{*}{$\begin{array}{c}\text { Moc } \\
\text { silnika } \\
\text { spali- } \\
\text { nowe- } \\
\text { go } \\
{[\mathbf{k W ]}}\end{array}$} & \multirow{2}{*}{$\begin{array}{c}\text { Licz- } \\
\text { ba/układ } \\
\text { cylindrów } \\
\text { R - rzędo- } \\
\text { wy } \\
\text { V - widla- } \\
\text { sty }\end{array}$} & \multirow{2}{*}{$\begin{array}{c}\text { Prędkośćc } \\
\text { obrotowa } \\
\text { silnika } \\
\text { [obr/min] }\end{array}$} & \multirow{2}{*}{$\begin{array}{c}\text { Obję- } \\
\text { tość } \\
\text { skoko- } \\
\text { wa } \\
\text { silnika } \\
{\left[\mathbf{d m}^{3}\right]}\end{array}$} & \multirow{2}{*}{$\begin{array}{c}\text { Średnie } \\
\text { ciśnie- } \\
\text { nie } \\
\text { uży- } \\
\text { teczne } \\
\text { [MPa] }\end{array}$} & \multirow{2}{*}{$\begin{array}{c}\text { Średnia } \\
\text { pręd- } \\
\text { kość } \\
\text { tloka } \\
{[\mathrm{m} / \mathbf{s}]}\end{array}$} & \multicolumn{2}{|c|}{$\begin{array}{c}\text { Zużycie jednostko- } \\
\text { we } \\
{[\mathrm{g} / \mathbf{k W h}]}\end{array}$} \\
\hline & & & & & & & & & $\begin{array}{c}\text { oleju } \\
\text { napędo- } \\
\text { wego } \\
\text { (paliwa) }\end{array}$ & $\begin{array}{c}\text { oleju } \\
\text { smar- } \\
\text { nego }\end{array}$ \\
\hline 1. & $\begin{array}{l}\text { V200 } \\
\text { (ST44) }\end{array}$ & $14 \mathrm{D} 40$ & 1470 & $12 / \mathrm{V}\left(45^{\circ}\right)$ & 750 & 150,6 & 0,81 & 7,5 & 228 & 2,7 \\
\hline 2. & BR232 & 5D49 & 2208 & $16 / \mathrm{V}\left(42^{\circ}\right)$ & 1000 & 200,8 & 1,20 & 8,67 & 215,6 & 4,08 \\
\hline 3. & $\begin{array}{l}\text { V200 } \\
\text { (M62) }\end{array}$ & $14 \mathrm{D} 40$ & 1470 & $12 / \mathrm{V}\left(45^{\circ}\right)$ & 750 & 150,6 & 0,81 & 7,5 & 228 & 2,7 \\
\hline 4. & EM62 & $645 \mathrm{E} 3 \mathrm{~B}$ & 2238 & $16 / \mathrm{V}\left(45^{\circ}\right)$ & 893 & 105,7 & - & - & - & - \\
\hline 5. & M62 & $12 \mathrm{CzN} 26 / 26$ & 1470 & $12 / \mathrm{V}\left(60^{\circ}\right)$ & 750 & 150,6 & 1,42 & 5,83 & 202,5 & 1,19 \\
\hline 6. & SM42 & $\mathrm{a} 8 \mathrm{C} 22$ & 588 & $8 / \mathrm{V}\left(50^{\circ}\right)$ & 1000 & 82,1 & 0,86 & 9,0 & 224,4 & 4,8 \\
\hline 7. & BR231 & $5 \mathrm{D} 49$ & 2208 & $16 / \mathrm{V}\left(42^{\circ}\right)$ & 1000 & 200,8 & 1,20 & 8,67 & 215,6 & 4,08 \\
\hline 8. & BR231 & CAT3606 & 1975 & $6 / \mathrm{R}$ & 1000 & 110,8 & 1,72 & $9 \div 10$ & 198 & 0,5 \\
\hline
\end{tabular}

2. Lokomotywa BR232 - badana w 2004 r. na oporniku wodnym w Pesa Bydgoszcz - rys. 7 「4].

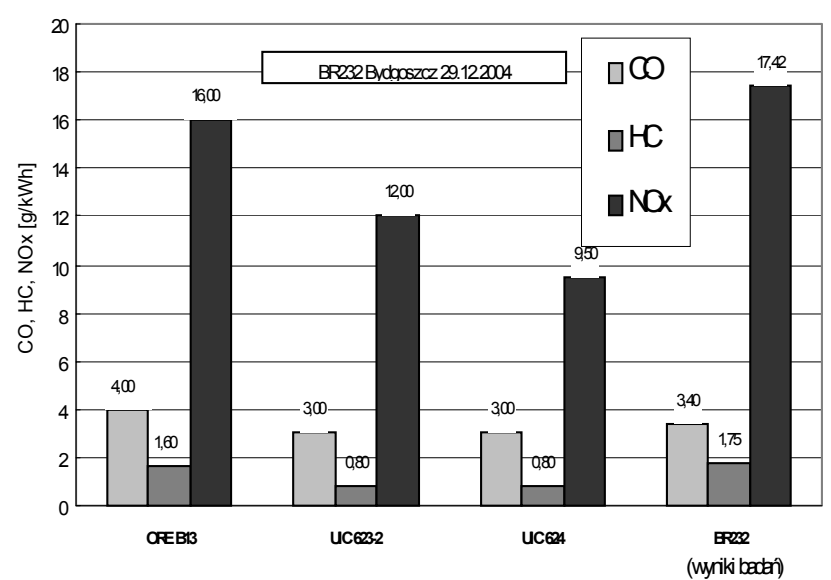

Rys. 7. Wyniki badań emisji spalin dla silnika 5D49 lokomotywy BR232

3. Lokomotywa V200 (ST44 - M62) nr 1241 - badana w sierpniu 2005 r. w Zakładach Napraw i Usług Technicznych w Rudzie Śląskiej, a po regulacjach i wymianach części badana powtórnie w ZNTK „Kuźnica Warężyńska" w Dąbrowie; w obu zakładach badania na oporniku wodnym - rys. 8 [8]. a)

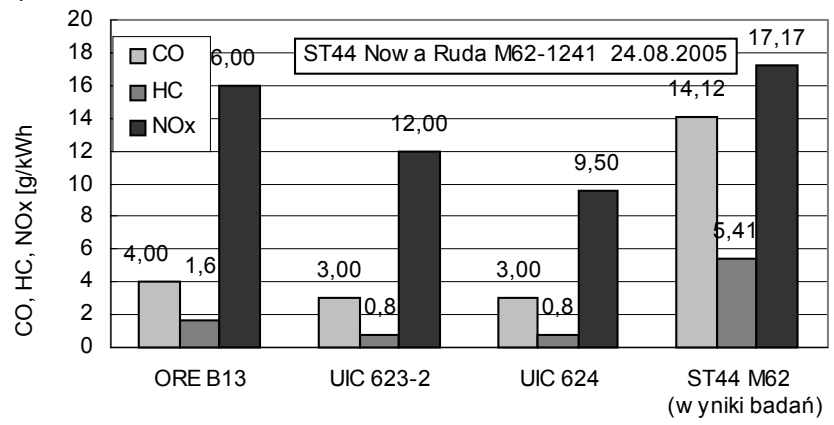

b)

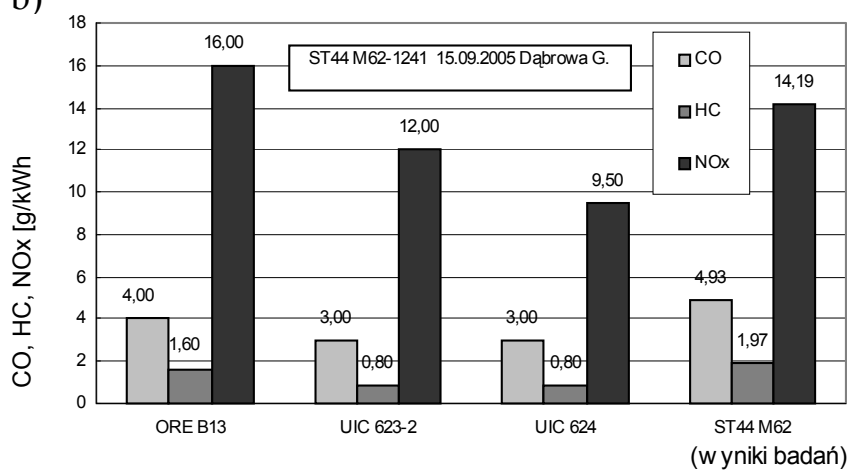

Rys. 8. Wyniki badań emisji spalin dla silnika 14D40 lokomotywy V200 (ST44 ; M62) nr 1241: $\mathrm{a}-$ przed regulacjami, $\mathrm{b}$ - po regulacjach 
4. Lokomotywa EM62-001 - badana w 2005 r. w fabryce lokomotyw Bumar-Fablok Chrzanów na oporniku wodnym - rys. $9\lceil 5\rceil$.

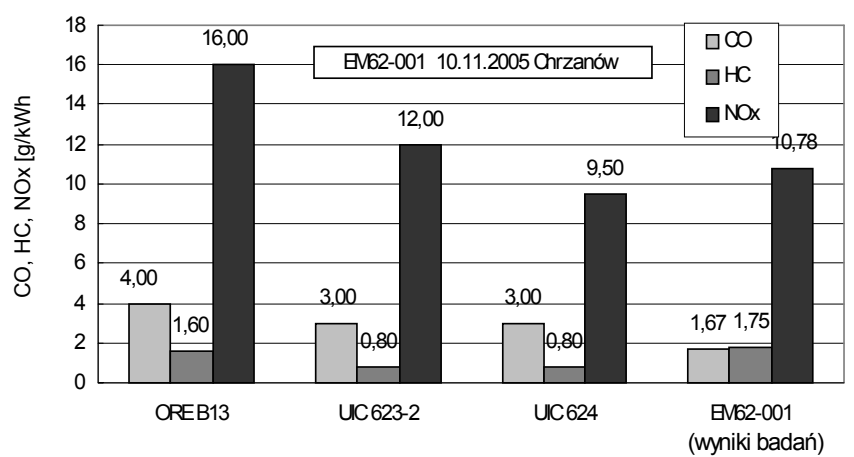

Rys. 9. Wyniki badań emisji spalin dla silnika 645E3B lokomotywy EM62

5. Lokomotywa M62 - 0161 - badana w 2006 r. w Pesa Bydgoszcz na oporniku wodnym - rys. 10 「6].

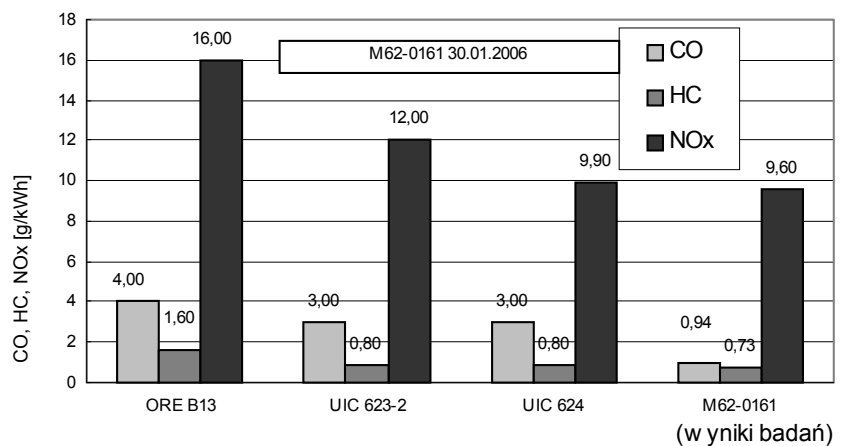

Rys. 10. Wyniki badań emisji spalin dla silnika 12CzN26/26 lokomotywy M62

6. Lokomotywa SM42 nr 2508 - badana w 2005 r. i 2006 r. w Zakładzie Taboru Kolejowego na oporniku wodnym w Poznaniu (03.11.2005 r. - przed regulacjami - 01.03.2006 r. - po regulacjach - rys. 11 [9].

a)

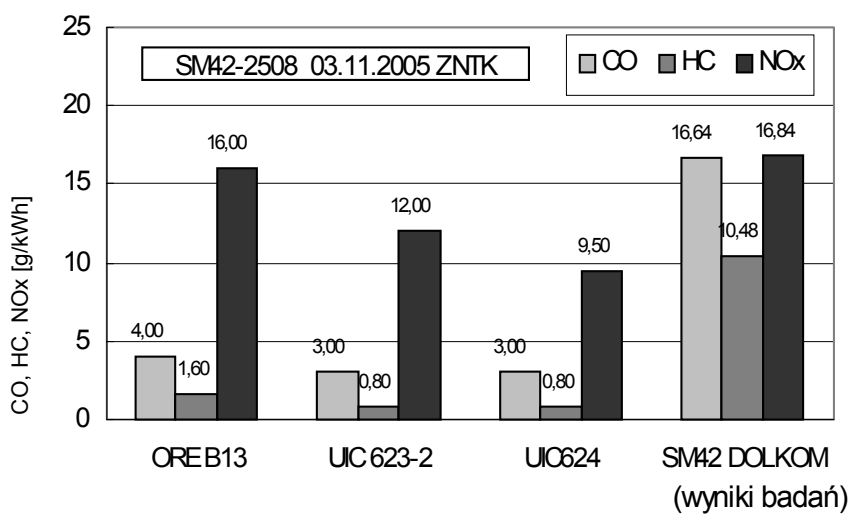

b)

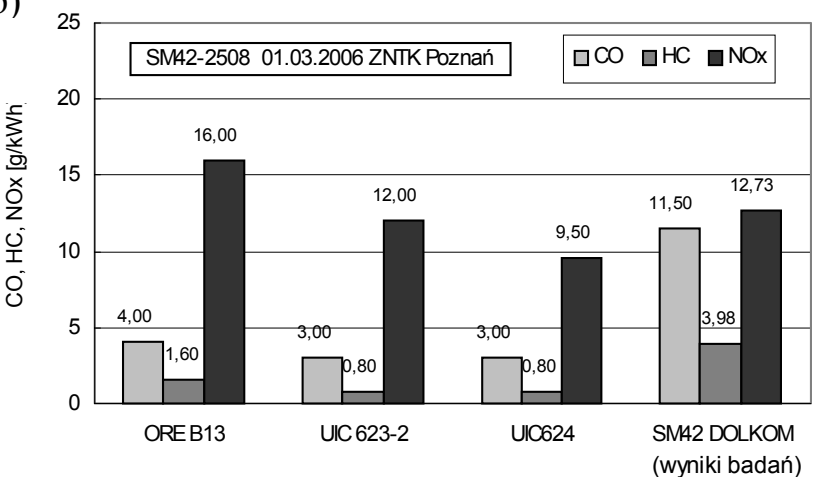

Rys. 11. Wyniki badań emisji spalin dla silnika a8C22 lokomotywy SM42

$\mathrm{a}$ - przed regulacjami, $\mathrm{b}$ - po regulacjach

7. Lokomotywa BR231 -badana w 2006r. w ZNTK

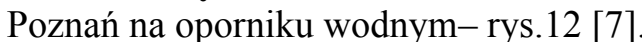

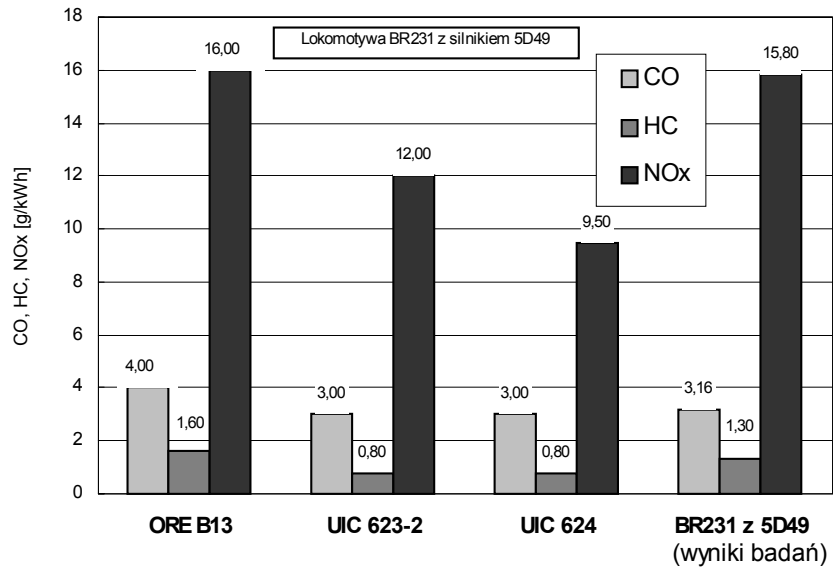

Rys. 12. Wyniki badań emisji spalin dla silnika 5D49 lokomotywy BR231

8. Lokomotywa BR231 - badana w 2006r. w ZNTK Poznań na oporniku wodnym - rys. 13 ¡7].

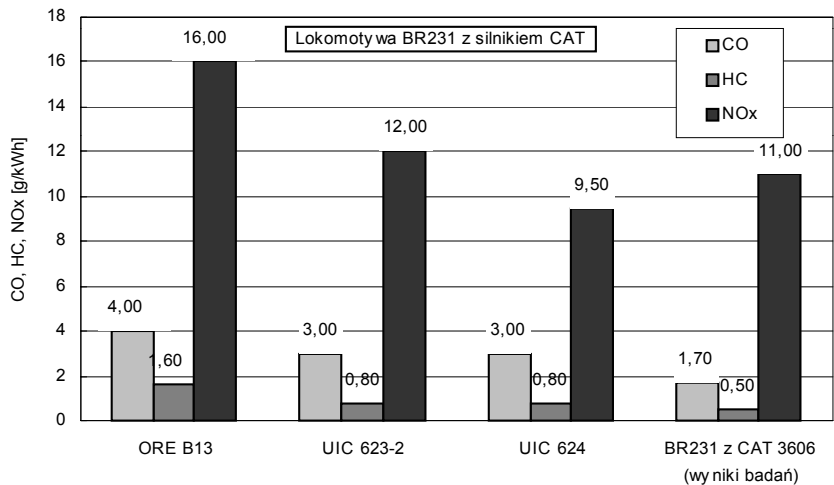

Rys. 13. Wyniki badań emisji spalin dla silnika CAT3606 lokomotywy BR231

Zestawienie uzyskanych wyników przedstawiono w tabeli 8 . 
Zestawienie wyników badań emisji składników toksycznych przez silniki spalinowe wg PN-EN ISO 8178-1 dla cyklu F

Tabela 8

\begin{tabular}{|c|c|c|c|c|c|c|}
\hline \multirow{2}{*}{ L.p. } & \multirow{2}{*}{$\begin{array}{c}\text { Typ/seria } \\
\text { badanej } \\
\text { lokomotywy } \\
\text { spalinowej } \\
\end{array}$} & \multirow{2}{*}{$\begin{array}{c}\text { Typ badanego } \\
\text { silnika } \\
\text { spalinowego } \\
\end{array}$} & \multirow{2}{*}{$\begin{array}{c}\text { Miejsce } \\
\text { prowadzenia } \\
\text { badań }\end{array}$} & \multicolumn{3}{|c|}{$\begin{array}{c}\text { Wartości emisji skladników } \\
\text { w g/kWh }\end{array}$} \\
\hline & & & & $\begin{array}{c}\text { CO } \\
\text { (tlenek wegla) }\end{array}$ & $\begin{array}{c}\text { HC (węglowo- } \\
\text { dory) }\end{array}$ & $\begin{array}{c}\mathrm{NO}_{\mathbf{x}} \\
\text { (tlenki azotu) }\end{array}$ \\
\hline 1. & V200(ST44) & $14 \mathrm{D} 40$ & $\begin{array}{l}\text { ZNTK } \\
\text { Poznań }\end{array}$ & 3,8 & 1,7 & 16,5 \\
\hline 2. & BR232 & $5 \mathrm{D} 49$ & $\begin{array}{c}\text { Pesa } \\
\text { Bydgoszcz }\end{array}$ & 3,40 & 1,75 & 17,42 \\
\hline 3. & V200 (M62) & $14 \mathrm{D} 40$ & $\begin{array}{c}\text { ZNTK } \\
\text { Kuźnica Warężyńska }\end{array}$ & 4,93 & 1,97 & 14,19 \\
\hline 4. & EM62 & 645E3B & $\begin{array}{l}\text { Bumar-Fablok } \\
\text { Chrzanów }\end{array}$ & 1,67 & 1,75 & 10,78 \\
\hline 5. & M62 & $12 \mathrm{CzN} 26 / 26$ & $\begin{array}{c}\text { Pesa } \\
\text { Bydgoszcz } \\
\end{array}$ & 0,94 & 0,73 & 9,60 \\
\hline 6. & SM42 & $\mathrm{a} 8 \mathrm{C} 22$ & $\begin{array}{l}\text { Zakład Taboru } \\
\text { Poznań }\end{array}$ & 16,64 & 10,48 & 16,84 \\
\hline 7. & BR231 & $5 \mathrm{D} 49$ & $\begin{array}{l}\text { ZNTK } \\
\text { Poznań }\end{array}$ & 3,16 & 1,3 & 15,8 \\
\hline 8. & BR231 & CAT3606 & $\begin{array}{l}\text { ZNTK } \\
\text { Poznań }\end{array}$ & 1,7 & 0,5 & 11 \\
\hline
\end{tabular}

Po wykonanych badaniach i przeprowadzonych analizach należy stwierdzić, że przy prawidłowych regulacjach, wymianach zużytych elementow oraz części, silniki spełniają w zasadzie dopuszczalne wartości dla norm i przepisów obowiązujących w latach, w których je wyprodukowano i wdrażano do eksploatacji. Zaznaczyć należy również, że na tle nowoczesnych jednostek CAT3606 i 12CzN26/26 wartości emisji z pozostałych silników, zwłaszcza dwusuwowych, są wyższe.

Biorąc ponadto pod uwagę to, że udział poszczególnych lokomotyw w pracach przewozowych i manewrowych w kraju jest wielokrotnie niższy od udziału transportu drogowego (zwłaszcza autobusowego i ciężarowego) emitowane przez nie składniki toksyczne do atmosfery stanowią niewielki ułamek procenta, tak więc oddziaływanie na środowisko naturalne będzie znikome.

Nie mniej jednak należałoby po każdej naprawie dokonywać okresowych sprawdzeń emisji spalin, zwłaszcza $\mathrm{w}$ odniesieniu do lokomotyw starszych wiekiem.

Przykładowe karty kontrolne i protokoły po takich badaniach, które winny być dołączone do świadectwa sprawności technicznej lokomotywy, przedstawiono w pracy $\lceil 1\rceil$ oraz w tabeli 9 .

Tabela 9

\begin{tabular}{|c|c|c|}
\hline $\begin{array}{c}\text { Nazwa } \\
\text { (pieczątka) } \\
\text { instytucji wykonującej } \\
\text { pomiary }\end{array}$ & $\begin{array}{c}\text { PROTOKÓL Z BADANIA (POMIARÓW) EMISJI } \\
\text { (STEZŻENIA) SKLADNIKÓW TOKSYCZNYCH } \\
\text { SPALIN SILNIKA SPALINOWEGO POJAZDU } \\
\text { TRAKCYJNEGO }\end{array}$ & $\begin{array}{c}\text { Data wykonania } \\
\text { pomiarów } \\
\text { Dzień/Miesiąc/Rok }\end{array}$ \\
\hline
\end{tabular}

I. Dane pojazdu i silnika:

1. Typ i rodzaj pojazdu

2. Rok produkcji pojazdu

3. Typ i moc silnika

4. Rok produkcji silnika

5. Przebieg pojazdu $(\mathrm{km})$

6. Czas pracy silnika (motogodziny) 
II. Warunki pomiaru:

1. Rodzaj testu: ISO 8178F; ISO 8178C1; ORE B13; ECE R-49; ESC; ELR; ETC *)

2. Aparatura pomiarowa:

- rodzaj (typ)

- rok produkcji (legalizacji)

3. Warunki atmosferyczne, godzina pomiarów:

- temperatura zewnętrzna

- ciśnienie atmosferyczne $\mathrm{hPa}$

- godzina pomiarów

III. Parametry mierzone:

- przed naprawą i regulacją silnika

Parametry napięciowo-prądowe

\begin{tabular}{|c|c|c|c|c|}
\hline \multirow{2}{*}{$\begin{array}{c}\text { Poz. } \\
\text { nastawnika }\end{array}$} & \multirow{2}{*}{$\begin{array}{l}\text { Prędkość } \\
\text { obrotowa } \\
\text { [obr/min] }\end{array}$} & \multicolumn{3}{|c|}{ Obciążenie prądnicy glównej } \\
\hline & & $\begin{array}{c}\text { Natężenie prądu } \\
{[\mathbf{A}]}\end{array}$ & $\begin{array}{c}\text { Napięcie prądu } \\
{[\mathrm{V}]}\end{array}$ & $\begin{array}{l}\text { Moc } \\
{[\mathbf{k W ]}}\end{array}$ \\
\hline 0 & & & & \\
\hline & & & & \\
\hline & & & & \\
\hline & & & & \\
\hline 0 & & & & \\
\hline
\end{tabular}

Wyniki badań emisji składników toksycznych

\begin{tabular}{|c|c|c|c|c|c|c|c|c|c|}
\hline \multirow[b]{2}{*}{$\begin{array}{c}\text { Poz. } \\
\text { nastawnika }\end{array}$} & \multicolumn{9}{|c|}{ Wartości emisji i zaczernienia } \\
\hline & $\begin{array}{c}\mathrm{CO} \\
{[\mathrm{ppm}]}\end{array}$ & $\begin{array}{c}\text { HC } \\
{[\mathrm{ppm}]}\end{array}$ & $\begin{array}{c}\mathrm{NO}_{\mathrm{x}}+\mathrm{HC} \\
{[\mathrm{ppm}]}\end{array}$ & $\begin{array}{l}\text { NOx }_{x} \\
\text { [ppm] }\end{array}$ & $\begin{array}{l}\text { NMHC } \\
\text { [ppm] }\end{array}$ & $\begin{array}{c}\mathrm{CH}_{4} \\
{[\mathrm{ppm}]}\end{array}$ & $\begin{array}{l}\mathrm{CO}_{2} \\
{[\%]} \\
\end{array}$ & $\begin{array}{c}\text { PM } \\
{\left[\mathrm{mg} / \mathbf{m}^{3}\right]}\end{array}$ & $\begin{array}{c}\text { Zaczernienie } \\
{\left[\mathrm{m}^{-1}\right]}\end{array}$ \\
\hline 0 & & & & & & & & & \\
\hline & & & & & & & & & \\
\hline & & & & & & & & & \\
\hline & & & & & & & & & \\
\hline & & & & & & & & & \\
\hline 0 & & & & & & & & & \\
\hline
\end{tabular}

- po naprawie i regulacjach silnika

Parametry napięciowo-prądowe

\begin{tabular}{|c|c|c|c|c|}
\hline \multirow{2}{*}{$\begin{array}{c}\text { Poz. } \\
\text { nastawnika }\end{array}$} & \multirow{2}{*}{$\begin{array}{l}\text { Prędkość } \\
\text { obrotowa } \\
\text { [obr/min] }\end{array}$} & \multicolumn{3}{|c|}{ Obciążenie prądnicy głównej } \\
\hline & & $\begin{array}{c}\text { Natężenie prądu } \\
{[A]}\end{array}$ & $\begin{array}{c}\text { Napięcie prądu } \\
{[\mathrm{V}]}\end{array}$ & $\begin{array}{l}\text { Moc } \\
{[\mathbf{k W ]}}\end{array}$ \\
\hline 0 & & & & \\
\hline & & & & \\
\hline 0 & & & & \\
\hline
\end{tabular}

Wyniki badań emisji składników toksycznych

\begin{tabular}{|c|c|c|c|c|c|c|c|c|c|}
\hline \multirow[b]{2}{*}{$\begin{array}{c}\text { Poz. } \\
\text { nastawnika }\end{array}$} & \multicolumn{9}{|c|}{ Wartości emisji i zaczernienia } \\
\hline & $\begin{array}{c}\mathrm{CO} \\
{[\mathrm{ppm}]}\end{array}$ & $\begin{array}{c}\text { HC } \\
{[\mathrm{ppm}]}\end{array}$ & $\begin{array}{c}\mathrm{NOx}+\mathrm{HC} \\
{[\mathrm{ppm}]}\end{array}$ & $\begin{array}{c}\text { NO }_{x} \\
{[p p m]}\end{array}$ & $\begin{array}{l}\text { NMHC } \\
\text { [ppm] }\end{array}$ & $\begin{array}{c}\mathrm{CH}_{4} \\
{[\mathrm{ppm}]}\end{array}$ & $\begin{array}{l}\mathrm{CO}_{2} \\
{[\%]} \\
\end{array}$ & $\begin{array}{c}\text { PM } \\
{\left[\mathrm{mg} / \mathrm{m}^{3}\right]}\end{array}$ & $\begin{array}{c}\text { Zaczernienie } \\
{\left[\mathrm{m}^{-1}\right]}\end{array}$ \\
\hline 0 & & & & & & & & & \\
\hline & & & & & & & & & \\
\hline & & & & & & & & & \\
\hline 0 & & & & & & & & & \\
\hline
\end{tabular}

Uwaga: Dla pojazdów z innq przekładniq niż elektryczna wypetnić poz. nast., prędkość i moc. 
IV. Wyniki pomiarów:

- CO (tlenek węgla) .................................. g/kWh

- HC (węglowodory) ............................. g/kWh

- $\mathrm{NO}_{\mathrm{x}}$ (tlenki azotu) ................................. g/kWh

- $\mathrm{NO}_{\mathrm{x}}+\mathrm{HC}$ (tlenki azotu i węglowodory)................ g/kWh

- NMHC (węglowodory bez metanu) ................... g/kWh

- $\mathrm{CH}_{4}($ metan) ................................. g/kWh

- $\mathrm{CO}_{2}$ (dwutlenek węgla) ..............................................

- PM (cząstki stałe) .................................................... g/kWh

- Zaczernienie ............................................................. $\mathrm{m}^{-1}$

V. Ocena wyników

Przeprowadzający badania i ocenę

*) niepotrzebne skreślić
Miejsce i data oceny

\section{PODSUMOWANIE}

Wykonane badania i przeprowadzone analizy skłaniaja do jednego wniosku, tzn. dla wszystkich sprowadzanych spalinowych pojazdów trakcyjnych, nie spełniających wymagań w zakresie emisji składników toksycznych spalin, należy dążyć docelowo do wymiany przestarzałych silników (zwłaszcza dwusuwowych) na silniki nowocześniejsze.

W ramach doraźnych rozwiązań, zmniejszających szkodliwe oddziaływanie na środowisko naturalne przez silniki starszej generacji poza wymienionymi już w pracy [2] należałoby:

- zainstalować pozasilnikowe układy oczyszczania spalin w postaci utleniających reaktorów katalitycznych dla zmniejszenia emisji tlenku węgla i węglowodorów, np. dwu lub jednowejściowe płaskie i okragłe katalizatory z thumikami lub bez

- zainstalować filtry cząstek stałych
- zainstalować filtry sadzowe (zamienne $\mathrm{z}$ filtrami cząstek stałych).

Ponadto naprawiane silniki lokomotyw zarówno podczas naprawy rewizyjnej jak i głównej powinny być każdorazowo poddawane badaniom (np. na oporniku) emisji składników toksycznych.

Z każdego przeprowadzonego badania należy sporządzić protokół z oceną (np. zaprezentowany w tabeli 9), który powinien być podstawą dla uzyskania przez pojazd świadectwa sprawności technicznej i dopuszczenia do eksploatacji na Polskich Liniach Kolejowych S.A.

Należy również zwrócić uwagę na to, że dla silników trakcji spalinowej winny obowiązywać jedne procedury przeprowadzania badań i jedne limity emisji spalin, tak jak ma to miejsce np. w Stanach Zjednoczonych i Japonii. 


\section{Literatura}

[1] Marciniak Z., Merkisz J., Pielecha I., Pielecha J.: Mobilne stanowisko do badań emisji sktadników toksycznych spalin silników spalinowych. Pojazdy Szynowe, nr 3/2002.

[2] Marciniak Z., Pielecha I.: Możliwości poprawy parametrów ekologicznych silników dla naprawianych $i$ modernizowanych lokomotyw spalinowych. Pojazdy Szynowe, nr 2/2004.

[3] Marciniak Z., Pielecha I.: Sprawozdanie z oceny silnika spalinowego lokomotywy V200 (ST44) w zakresie emisji sktadników toksycznych spalin. Opracowanie SB-2252. Praca IPS „Tabor". Poznań 2004.

[4] Marciniak Z., Pielecha I.: Sprawozdanie z badania emisji składników toksycznych spalin silnika 5D49 lokomotywy spalinowej BR232. Opracowanie SB-2259, Praca IPS „Tabor”. Poznań 2005.

[5] Marciniak Z., Pielecha I.: Sprawozdanie z badania emisji składników toksycznych spalin silnika lokomotywy spalinowej EM62-001. Opracowanie SB-2278, Praca IPS „Tabor”. Poznań 2005.

[6] Marciniak Z., Pielecha I.: Sprawozdanie z badania emisji składników toksycznych spalin silnika lokomotywy spalinowej M62-0161. Opracowanie SB-2284, Praca IPS „Tabor”. Poznań 2006.

[7] Marciniak Z., Pielecha I.: Sprawozdanie z badania emisji składników toksycznych spalin silników 5 D49 i CAT3606 lokomotyw spalinowych BR231/BR232. Opracowanie SB-2285, Praca IPS ,Tabor”. Poznań 2006.

[8] Pielecha I., Czerwiński J.: Sprawozdanie z badania emisji sktadników toksycznych spalin silnika lokomotywy spalinowej V200 (ST44M62) $n r$ 1241. Opracowanie SB-2275. Praca IPS ,Tabor”. Poznań 2005.
[9] Pielecha I., Czerwiński J.: Sprawozdanie z badania emisji składników toksycznych spalin silnika lokomotywy spalinowej SM42 nr 2508. Opracowanie SB-2277, Praca IPS „Tabor”. Poznań 2006.

[10] Pielecha I., Pielecha J.: Tendencje w przepisach dotyczacych emisji zwiazków toksycznych przez silniki spalinowe pojazdów szynowych. Pojazdy Szynowe, $n r$ 1/2005.

[11] Raczyński J.: Ograniczanie emisji spalin $z$ silników kolejowych w prawie unijnym. Technika Transportu Szynowego 2004, nr 7/8.

[12] Karta UIC 624 Badanie emisji gazów wydechowych silników spalinowych trakcyjnych. Wyd. 2 z kwietnia 2003.

[13] Directive 97/68/EC of the European Parliament and of the council z 16.12.1997, wydane 27.02.1998.

[14] Directive 2004/26/EC of the European Parliament and of the council z 21.04.2004.

[15] Raport ORE B13 Rp. 22, Dopuszczenie do eksploatacji oraz utrzymywanie silników spalinowych. Graniczne wartości emisji sktadników toksycznych spalin silników spalinowych. Utrecht, kwiecien 1978 r.

[16] Norma PN-EN ISO 8178-1, Silniki spalinowe ttokowe. Pomiar emisji spalin. Pomiar emisji składników gazowych i czastek statych na stanowisku badawczym. Wyd. styczeń 1999.

[17] Norma PN-EN ISO 8178-4, Silniki spalinowe tlokowe. Pomiar emisji spalin. Cykle badawcze silników o różnym zastosowaniu. Wyd. styczeń 1999.

[18] Karta UIC 623-2, Badania homologacyjne silników spalinowych pojazdów napędowych. Wyd. 3 z kwietnia 2005. 